Primljen / Received: 25.9.2012.

Ispravljen / Corrected: 12.12.2012.

Prihvaćen / Accepted: 27.12.2012.

Dostupno online / Available online: 15.1.2013.

\section{Preliminary design of an immersed tunnel in Izmir}

\section{Authors:}

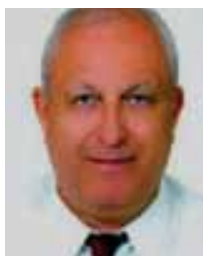

Assoc.Prof. İsfendiyar Egeli, PhD. CE Izmir Institute of Technoloqy Department of Civil Engineering isfendiyaregeli@iyte.edu.tr

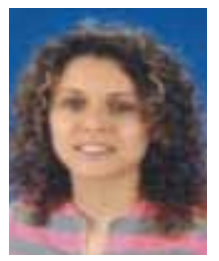

Nisa Kartaltepe, MSc. student Izmir Institute of Technoloqy Department of Civil Engineering nisa5b@hotmail.com

\section{Preliminary design of an immersed tunnel in Izmir}

Possibilities for building the Izmir Bay Immersed Tube Tunnel are analyzed in the paper. Study results show that the tunnel construction is feasible if a particular soil improvement is conducted properly. A minimum SPT-N value, compatible with concrete to be used in construction of the immersed tube, is defined so as to enable subsequent improvement of soil density. This procedure enables achievement of the minimum post-improvement soil-structure interaction stiffness level, as well as fulfilment of all other geotechnical criteria. This was demonstrated using the existing data about sub-sea soil in which the tunnel construction is planned.

\section{Key words:}

Immersed tunnels, sub-sea structures, soil improvement, soil-structure interaction stiffness

Stručni rad

İsfendiyar Egeli, Nisa Kartaltepe

\section{Idejni projekt uronjenog tunela u Izmiru}

U radu se analizira mogućnost izgradnje uronjenog tunela ispod Izmirskog zaljeva. Rezultati istraživanja pokazuju da je izgradnja tunela izvediva ukoliko se na ispravan način obavi određeno poboljšanje tla. Za određivanje naknadnog poboljšanja gustoće tla, definirana je minimalna vrijednost SPT-N koja je kompatibilna s betonom predvidenim za izgradnju uronjenog tunela. Ovaj postupak omogućuje osiguranje minimalnog naknadnog poboljšanja krutosti medudjelovanja tla i građevine uz ispunjavanje svih ostalih geotehničkih kriterija. Navedeno je dokazano pomoću postojećih podataka o podmorskom tlu na kojem je predvidena izgradnja tunela.

Ključne riječi:

uronjeni tunel, podmorske gradevine, poboljšanje tla, krutost veze izmedu tla i gradevine

Fachbericht

İsfendiyar Egeli, Nisa Kartaltepe

\section{Vorplanung des Unterwassertunnels in Izmir}

Die in der vorliegenden Arbeitdurchgeführte Analyse der Ausführbarkeiteines Unterwassertunnels unter der Bucht von Izmir (IBITT - Izmir Bay Immersed Tube Tunnel) lässt darauf schliessen, dass unter der Bedingung einer entsprechenden Bodenverbesserung, die Konstruktion des geplanten Bauwerks möglich ist. Um die nachträgliche Verbessung der Bodendichte zu ermitteln, ist der minimale SPT-N Wert, kompatibel mit dem für die Ausführung vorgesehenen Betons, angenommen. Alle anderen geotechnischen Kriterien erfüllend, ermöglicht dieses Verfahren eine minimale nachträgliche Verbessung der Steifigkeit der Boden-Bauwerk-Interaktion. Dies ist mittels bestehender Daten, die den Unterwasserboden im Gebiet der geplanten Erbauung des IBITT betreffen, erwiesen. 


\section{Introduction}

In order to relieve traffic congestion in the City of Izmir for people living on the north and south sides of the Izmir Bay, a pre-feasibility study and preliminary design were made for the proposed immersed tube tunnel which is to run along the Inciraltı-Çiğli, figure 1. This design work is based on information obtained from local, municipal and government authorities. The proposed Izmir Bay Immersed Tube Tunnel (IBITT) will measure $40 \mathrm{~m}$ in width and $7.6 \mathrm{~km}$ in length. The tunnel is characterized by a rectangular cross-section, and will have $2 \times 3$ road traffic lanes on both sides, and a $2 \times 1$ railway tracks in the middle. An immersed tube tunnel construction is considered along this route for the following reasons:

- Izmir Bay is relatively shallow ( $<25 \mathrm{~m}$ ) and so it meets the maximum depth criteria (60 m) for constructability (figure 2) [1, 2]

- The seabed soil is generally made of the non-cohesive very loose to loose silt-sand mixtures, with a very low bearing capacity, which can however be improved by a suitable soil-improvement technique

- By selection of a straight-line route for the immersed tube tunnel between two sides of the bay, the tunnel can be connected to the existing highway junctions and nearby railway lines

- The buried tube tunnel surrounded with a selected compacted fill in the tunnel's dredged ditch has a better earthquake response when compared to a much heavier elevated bridge structure

- Substantial foundation cost savings, compared to other fixed-crossing options, will be realized due to the fact that the immersed tube tunnel makes use of water-buoyancy (Archimedes Principle), which enables smaller load transfer to the very loose seabed soil with very low bearing capacity

- Excessive bedrock depth (>100 m) for most of the proposed sea crossing route, which is why all piles would need to be frictional in very loose deposits whose thicknesses vary from $30 \mathrm{~m}$ (in the south) to $280 \mathrm{~m}$ (in the north); consequently, excessive pile settlements might occur during seismic action in this earthquake-prone region.

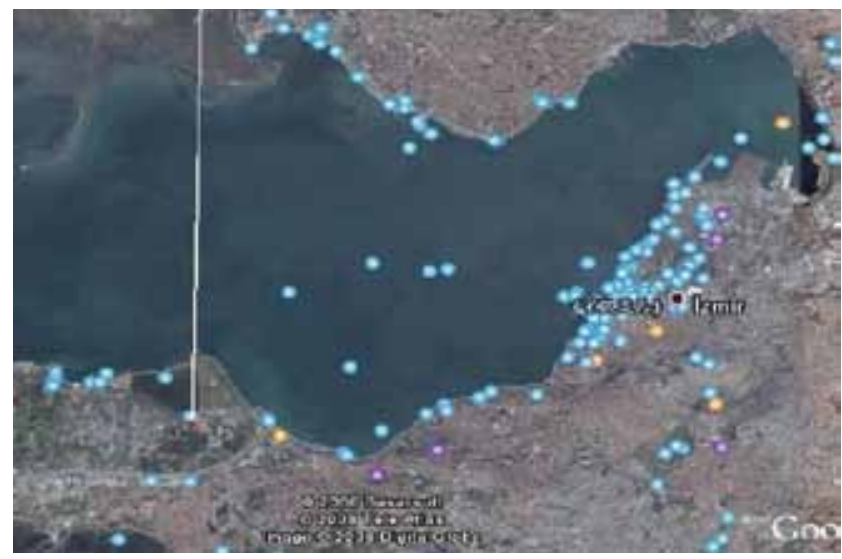

Figure 1. Alignment of the proposed Izmir Bay Immersed Tube Tunnel (IBITT)

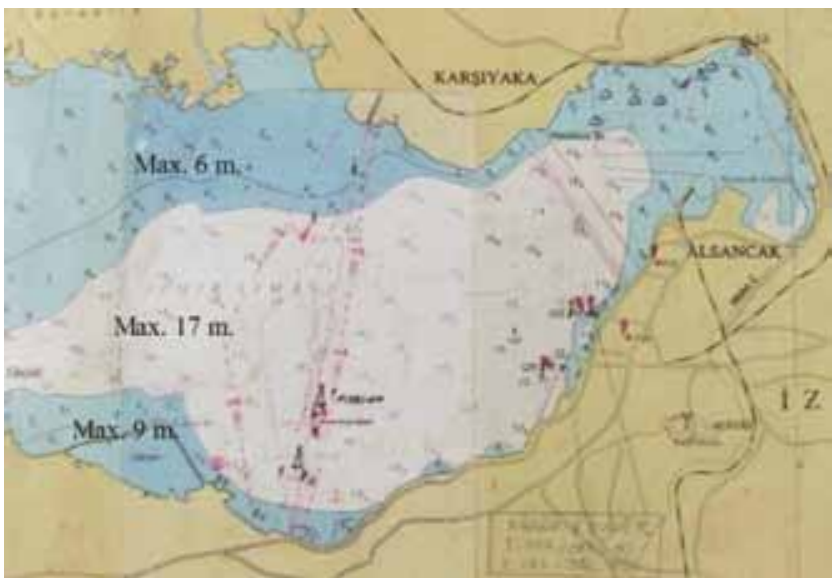

Figure 2. Maximum water depths in Izmir Bay near the proposed IBIIT route

\section{Project purpose and approximate costs}

Construction of an immersed tube tunnel across the Izmir Bay will enable:

- Direct link to the existing highway and railway junctions in Çiğli (in the north) and Uçkuyular (in the south) districts. Also, traffic congestion in the centre of the city will diminish substantially as it will no longer be needed to make a detour around the bay through the centre of the city,

- The proposed IBITT will also shorten the highway commuting distance between the Çiğli and Adnan Menderes Airports by about $8 \mathrm{~km}$, while the connecting distance between the Çeşme-Motorway and Izmir-Çanakkale Highway will be shortened by about $40 \mathrm{~km}$,

- The tunnel will enable easy, comfortable and quick link between the Izmir city centre and various nearby business and holiday centres. In addition, the economic activity in the city will be increased,

- Lower petrol consumption due to shorter travel distances, and hence less foreign exchange will have to be paid for the import of expensive petrol, which will be highly beneficial to national economy,

- Quality of life and air for people living in the city of Izmir will be improved, as transport difficulties and environmental pollution will decrease.

To gain an idea about the feasibility of the project, construction costs should be estimated based on the assumed unit rates, which were taken from the Marmaray (immersed tube tunnel) Project, currently under construction in Istanbul, Turkey [1]. The Marmaray's immersed tube tunnel is 1,4 km long, 15,3 m wide, and its unit construction cost amounts to about US\$100 million/km, whereas the proposed Izmir Bay Immersed Tube Tunnel (IBITT) is 7,6 km long and 39,8 m wide. Although both tunnels have 2 railway lines, the proposed IBITT also contains $2 \times 3$ road traffic lanes on each side of the tunnel. To estimate the construction cost of the proposed IBITT, the unit cost of 
the ongoing Marmaray Project was multiplied by the ratios of the "widths" and "lengths", compared to the proposed IBITT, and an approximate cost of US\$ 2 billion [(39.8/15.3) x7,6x100] was obtained. However, this price represents the lower limit of the expected costs, as the assumed unit rate does not cover the cost of dredging/excavation/backfilling, and substantial soil improvements as needed for the proposed IBITT, due to presence of very loose and thick seabed soil above the bedrock, which dips towards the north. Thus, the total cost estimate of the proposed IBITT could be closer to US $\$ 3$ billion. Furthermore, if the existing Izmir Port (Alsancak) Container Terminal does not move to Çandarlı location (as is currently planned), then the dredging and backfilling cost will further increase by 10 $\%$, as the depths of dredging will double to include the depths of up to about $25 \mathrm{~m}$. In this case, the total cost may attain almost US $\$ 3,3$ billion. Using this probable cost, the return of investment (ROI) period within the maximum Built-OperateTransfer (BOT) period of 30 years needs to be re-studied, so as to find out whether the project can be constructed within a reasonable period of time to ensure its economic viability. For the time being, this possibility will be excluded from the scope of this study.

If the proposed IBITT is implemented, it is expected from the surveys made by the Turkish State Directorate of Highways (KGM) that 40,000 vehicles/day/direction will use the tunnel, and the Turkish Ministry of Transport and Communications will guarantee this number to the BOT bidders during the bidding process. This means that the Ministry will subsidize the successful bidder, if the number drops below 40,000 vehicles/ day/direction, during any day of tunnel operation within the BOT period. The user-pays concept will be applied for road traffic lanes to subsidize the cost of the electrical railway transport. In this respect, US\$7,5/vehicle/direction will be charged as the crossing fee. The daily income in both directions will reach US\$ 0,6 million, or US\$219 million annually. Therefore, the tunnel construction costs could be reimbursed within a reasonable period of 15 years. An additional income to be generated in subsequent years within the 30-year BOT period, and from an increase in the number of vehicles, is reserved for the proposed IBITT's profit, and for its maintenance and operation costs. The income from railway transport is not added to these depreciation costs, and it will be a source of additional income for the successful bidder. Also, the country (Turkey) will save on the cost of the imported petrol that would be otherwise spent by these 40,000 vehicles/day/direction, which unnecessarily travel about $40 \mathrm{~km}$ around the bay, consuming about 180,000 litres/day of petrol, costing US\$0,44 millions/day or US\$ 161 million/year, or US\$2,42 billion in 15 years. This corresponds to about $73,3 \%$ of the tunnel cost. In other words, assuming that the price of petrol will stay constant at its current unit price (US\$ 2,45 /liter) for the next 20,5 years, the amount of petrol saved by the country will be equal to the cost of the tunnel. Currently the price of petrol in Turkey is among the highest in the world, and it is bound to increase steadily, as the world population and petrol demand is likely to increase faster than the petrol supply over the next few decades. Supplies from proven existing reserves may soon be incapable of meeting the demand of the ever increasing and industrializing world population. If we assume that the present day rate of petroleum demand will remain constant, it may reasonably be expected that by 2050 most of the world's known oil reserves will be consumed, and that the petrol unit price will go up even further. Thus, on the one hand, the country will save a lot of money that would otherwise need to be spend to import the increasingly expensive petrol while, on the other hand, the global environment will be spared from a lot of unwanted greenhouse gas emissions. People in their cars will also save both time (1,5-2 hours/day to travel around the Bay in both directions) and money (instead of paying US\$ 7,0 for 2,85 litres of petrol consumed to travel both ways, they would happily pay a possible user fee of US\$ 7,5/vehicle/passage to save time, in today's unit prices. With only the user fee considered, the successful bidder company, who wins the BuiltOperate-Transfer (BOT) lease, will recover its investment costs (of approximately US\$ 3 billion) in no more than 15 years, while the company will reap profit in the remainder of the BOT period (generally lasting about 30 years). This means that the proposed IBITT is economically feasible and profitable. However, there are some uncertainties regarding the project's construction costs, due to limited sea-bed sub-soil data, which will influence the type, extent and costs of the ground improvement needed on this project. Once more site investigation data are gathered, this preliminary design and its cost estimate should be reviewed and revised, if necessary.

\section{Properties of the proposed Izmir Bay Immersed Tube Tunnel (IBITT)}

First, the analysis focused on the existing soil in the project zone, location of the existing highway/railway junctions, other proposed highway/railway routes, and on the most suitable and shortest possible straight alignment for the proposed IBITT project. In order to decide on the most favourable tunnel alignment, presenting minimum construction costs, and meeting safety requirements with regard to static and dynamic loads, the following criteria were set:

- the route should not cross known fault lines

- additional safety measures should be taken in the vicinity of fault lines, including protection against fire, chemical spills, electrical breakdowns, and water leakage into the tunnel in case of static and dynamic (earthquake) loads

- the structure's passive (selection of straight-line alignment) and active (installation of flexible elastomeric bearings) damping capacity with regard to dynamic forces should be ensured

- tunnel units should work in compression under static load - well-developed areas should be avoided as tunnel exit/ entrance points so as to avoid traffic jams. Therefore, it was established in this preliminary design study that the 
most suitable route for the proposed IBITT project is the the straight-line alignment between Inciraltı and Çiğli, as shown in Figure 1. Maximum water depths near to the proposed IBITT project route are shown in Figure 2 [2].

The total length of the tunnel (from the south entrance to the north entrance) is $7,58 \mathrm{~km}$. The tunnel will be made of 76 prefabricated immersed tunnel units, each about $100 \mathrm{~m}$ in length. The existing borehole data obtained from the State Ports and Airports Authority (DLH) show that the maximum water depth above the tunnel is about 17,5 m under current conditions (i.e. if the tunnel is placed in a dredged trench, where the top level of the proposed IBITT will correspond to the existing seabed level). However, if the present Izmir Port does not move to nearby Çandarlı site, to allow very large ships to use the Port and the Bay, the IBITT should be placed in a deeper channel with minimum water depth of $27 \mathrm{~m}$, which means that the tunnel should be placed in a $10 \mathrm{~m}$ deeper dredged trench to allow for the passage of big ships. In the engineering part of this preliminary design study, it is assumed that Izmir port will not be moved to a new location and, hence, that the lowering of the IBITT will not be necessary (this decision is to be made only after a full feasibility study, with a detailed site investigation, is completed). As roads can be designed to steeper gradients compared to railways, the maximum allowable gradient for the proposed metro railway has been adopted when selecting the maximum gradient for both sloping sections of the proposed IBITT project. Thus a $2,5 \%$ gradient was adopted for the $1120 \mathrm{~m}$ long south-side sloping section, while a milder gradient of $1 \%$ was selected for the $2800 \mathrm{~m}$ long north-side sloping section. The flat middle section of the tunnel (with zero gradient) will be $5,56 \mathrm{~km}$ long and will consist of 60 units, while the sloping end sections will be about $2 \mathrm{~km}$ long and will be made of 16 units. One unit at the sloping south-side section crosses a man-made narrow embankment (fill) enclosing a section of the Bay, where the ground surface is at $1 \mathrm{~m}$ above the mean sea level, which is why this tunnel unit will be put in place using the 'cut and cover' method. All other units of the tunnel in the flat middle section will be constructed using the "immersed tube tunnel construction technique" [1]. Each unit of the proposed IBITT will measure $10 \mathrm{~m}$ in height and 39,8 $\mathrm{m}$ in width. In the middle, there will be a $10,6 \mathrm{~m}$ wide rail transport corridor with 2 railway lines, while the 2 edgecompartments on both sides will contain $2 \times 3$ road traffic lanes lanes. The cross section and longitudinal section of the proposed IBITT are shown in Figures 3 and 4 [2].

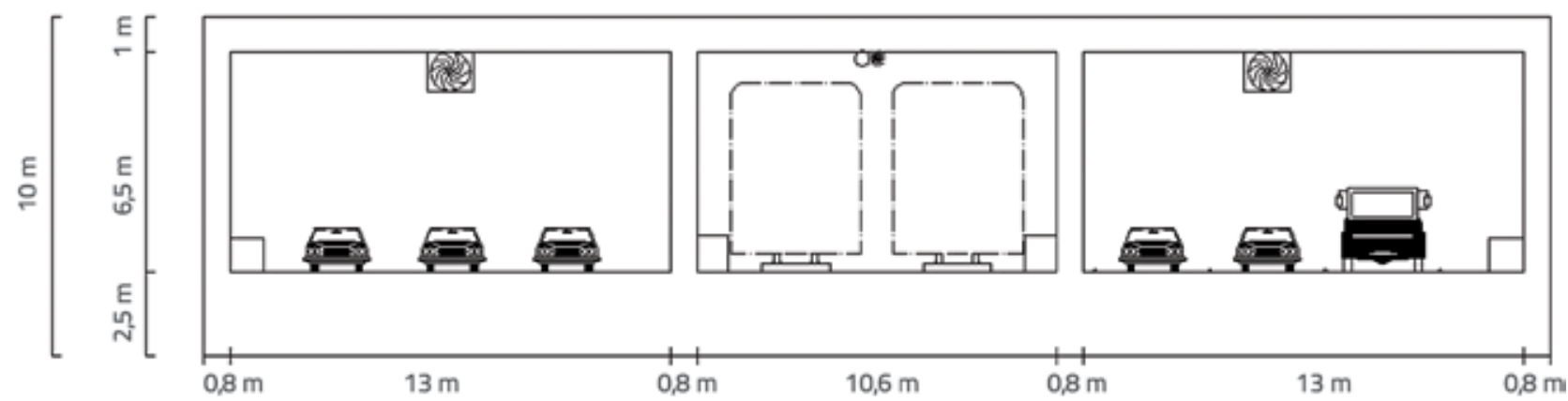

Figure 3. Lateral section/cross-section of the proposed IBITT structure

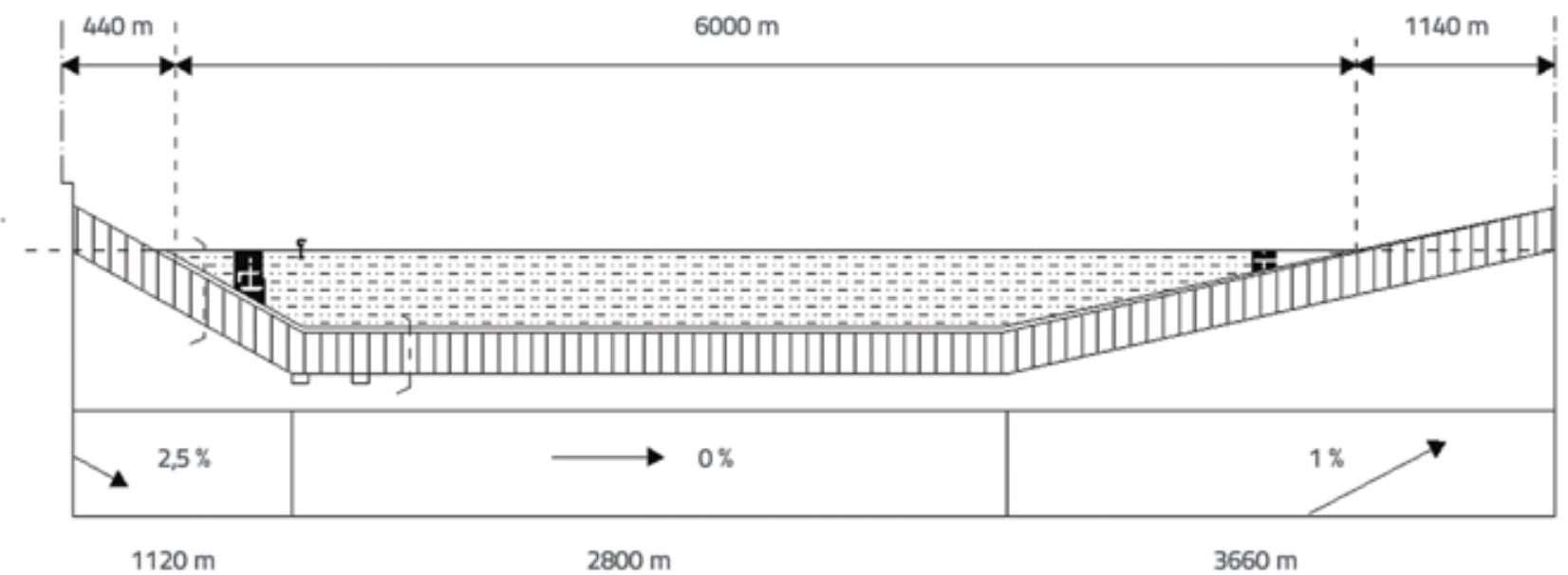

Figure 4. Longitudinal section of the proposed IBITT structure 


\section{Current allowable bearing capacity of the Izmir Bay's subsea soil}

By definition, the ultimate bearing capacity is the maximum safe carrying capacity (in stress terms) of the soil, without shear failure and intolerably large total and differential settlements. The ultimate bearing capacity is calculated using two different criteria: a) ultimate bearing capacity for shear failure criteria " $q_{u}$ " divided by the factor of safety "FS", and b) tolerable settlement criteria. The smaller value of the two is adopted as the "net allowable bearing capacity", $q_{a(\text { net) }}$. To find the allowable bearing capacity from shear failure viewpoint, the ultimate bearing capacity, " $q_{u}$ ", is divided by the selected factor of safety "FS", and then the allowable bearing capacity for shear failure, " $q_{a}$ " (or sometimes termed as $\left.q_{a(1)}\right)$, is found by;

$q_{a}=\frac{q_{u l t}}{F S}$

Where the term " $q_{u l t}$ is the final carrying capacity of the seabed sub-soil; it is calculated from the following equation 2 [3] as follows:

$\mathrm{q}_{\mathrm{ult}}=0,04882\left(3 \cdot N^{2} \cdot B \cdot R^{\prime \prime}{ }_{\mathrm{w}}+5 \cdot\left(100+N^{2}\right) \cdot D \cdot R_{\mathrm{w}}\right)[\mathrm{kPa}]$

In equation 2 , the factor 0,04882 is obtained by conversion from the original equation in parenthesis in imperial units (psf) to the $\mathrm{SI}$ units $(\mathrm{kPa}), N$ is the standard penetration resistance, $B$ is the foundation width $(39,8 \mathrm{~m}) ; R_{w}^{\prime}$ and $R_{w}$ are the mean sea level (or the ground water table-GWT) correction factors, (both amounting to 0,5 in our case), D is the buried distance $(\mathrm{m})$ below sea bed, which is equal to the immersed tunnel unit's height $(10 \mathrm{~m})$. Regarding the Standard Penetration Test- $\mathrm{N}$ values to be used in equation 2 , average $\mathrm{N}$ values from 3 boreholes drilled at the Izmir Bay by the State Ports and Airports Authority (DLH), closest to the proposed IBITT alignment, were used. Borehole locations are shown in Figure 5 [2].

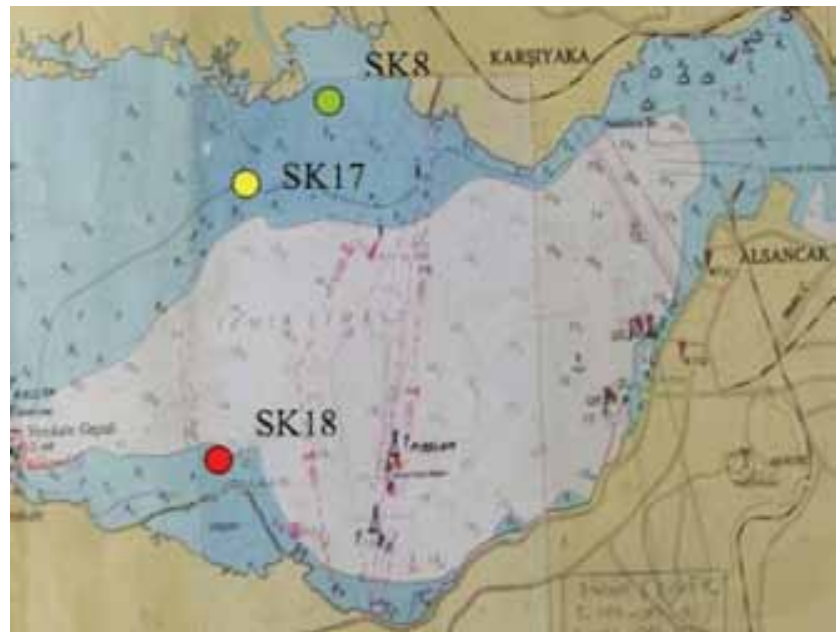

Figure 5. Standard Penetration Test (SPT) locations nearest to the proposed IBITT route
According to the existing site investigation report (State Ports and Airports Authority ( $\mathrm{DLH}, 1985)$ that contains various borehole logs with the corresponding laboratory test results, most of the subsoil profile along the proposed tunnel's alignment is generally composed of the non-cohesive loose to very loose silt-sand mixture of layers, with the total thickness varying from 30 to 280 $\mathrm{m}$ below the existing seabed. The depth to bedrock at the south portal (Üçkuyular) is about $35 \mathrm{~m}$, while it is about $285 \mathrm{~m}$ below the existing ground surface at the north portal (Cigli), which is about $1 \mathrm{~m}$ above the existing mean sea level. Using these test results, the corrected average SPT-N value for the first $1,1 \mathrm{~km}$ from the Uckuyular (south portal) entrance amounts to 29 . It is 3 for the final 2,8 km from the Cigli (north portal) entrance, and 4 for the $3,7 \mathrm{~km}$ long central portion of the tunnel route. Then the ultimate bearing capacity for the central portion covering most of the alignment can be found by taking SPT- $N=4$, and the factor of safety "FS" = 3 from the equation 2, as follows:

$$
\begin{aligned}
& \mathrm{q}_{\text {ult }}=0,04882\left(3 \cdot 4^{2} \cdot 39,8 \cdot 0,5+5 \cdot\left(100+4^{2}\right) \cdot 10 \cdot 0,5[\mathrm{kPa}]\right. \\
& \mathrm{q}_{\text {ult }}=188,2[\mathrm{kPa}] \\
& \mathrm{q}_{\mathrm{a}} \text { ili } \mathrm{q}_{\mathrm{a}(1)}=188,2 / 3=62,7[\mathrm{kPa}]
\end{aligned}
$$

This value of $62,7 \mathrm{kPa}$ represents the allowable bearing capacity, $q_{a}$ or $q_{a(1)}$ from the shear strength viewpoint. It can be noted that the maximum allowable settlement value for the immersed tube tunnels constructed in Hong Kong, with similar subsoil and properties, amounts to $25 \mathrm{~mm}$ [4]. Thus, by applying this criterion, the maximum allowable settlements could be calculated using the following equation 6 [3]:

$$
\begin{aligned}
& q_{a(2)}=35 \cdot\left(N_{\text {cor }}-3\right) \cdot\left(\frac{B+0,3048}{2 B}\right)^{2} \cdot R_{w}[k P a] \\
& N_{\text {cor }}=N \cdot\left(\frac{50}{p^{\prime}+10}\right)
\end{aligned}
$$

Where, $N_{\text {cor }}$ is the corrected SPT-N value calculated according to the equation 7 , and $p^{\prime}$ is the maximum effective stress increase after construction in the middle of the soil layer, in between the seabed and the bedrock, as shown in equation 8 :

$p^{\prime}=\gamma^{\prime} \cdot h$

Here, $\gamma^{\prime}$ is the submerged unit weight of the soil underwater, $h$ is the half thickness of the loose layer between the seabed and the rock head. If the $p^{\prime}$ value exceeds the limit value of $281,2 \mathrm{kPa}$, then the $p^{\prime}$ value is used as it is, since the subsoil is non-cohesive (granular) in nature [3]. If we assume that the average depth to bedrock (h) is $150 \mathrm{~m}$ at the mid-section of the alignment, and if we take that the saturated unit weight of soil is $18 \mathrm{kN} / \mathrm{m}^{3}$ (or submerged unit weight of $8,0 \mathrm{kN} / \mathrm{m}^{3}$ ), then $p^{\prime}$ amounts to $600 \mathrm{kPa}$ at $75 \mathrm{~m}$ in depth, which exceeds the limit value of $281,2 \mathrm{kPa}$ and is taken as it is. By inserting $\mathrm{SPT}-\mathrm{N}_{\text {cor }}=4$ into the equation 3 , the ultimate bearing capacity of sub-soil amounts to $4,4 \mathrm{kPa}$ for the maximum tolerable 
settlement of $25 \mathrm{~mm}$, as shown in the equations 9 below [3]. It should be noted that equation 9 was developed to calculate $\left(\mathrm{q}_{\mathrm{a}(2)}\right)$ for maximum $25 \mathrm{~mm}$ tolerable settlement.

$q_{a(2)}=35 \cdot(4-3) \cdot\left(\frac{39,8+0,3048}{2 \cdot 39,8}\right)^{2} \cdot 0,5$

When both allowable bearing capacity values, obtained from equations 5 and 9 , are compared, the smaller one $\left(q_{a(2)}\right)$ is taken as the governing value for the "net allowable bearing capacity" along the alignment, including the central section. This is a very low value that points to the need for ground improvement. Generally, the maximum tolerable settlement criteria govern the net allowable bearing capacity calculation, as also shown in Figure 6 taken from [5]. It should be noted that the horizontal axis denotes bearing capacities in terms of stress, where $\left.q_{a(2)}<q_{a(1)}<q_{u l t}\right)$.

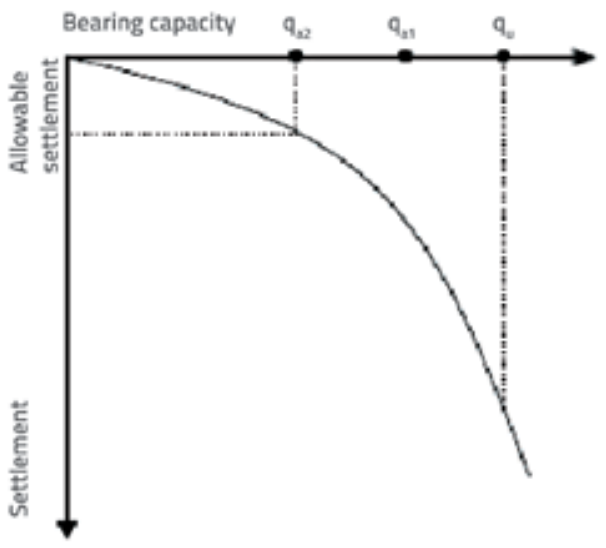

Figure 6. Basis for 'tolerable settlement' criteria used to assess allowable bearing capacity

On the other hand, an average SPT- $\mathrm{N}$ value in the northern quarter of the alignment amounts to 3 , including the northern portal site, where the total loose soil thickness reaches about $280 \mathrm{~m}$ below seabed level and above bedrock. This corresponds to almost zero net allowable bearing capacity $\left(\mathrm{q}_{\mathrm{a}(\text { net }}=0 \mathrm{kPa}\right)$ and hence, soil improvement along the tunnel alignment is necessary, so as to avoid excessive total and differential settlements, which are highly detrimental to the tunnel structure.

\section{Static analysis for settlement calculations}

Although a strong mechanical bond exists between dry particles of non-cohesive loose sand and silt-sand mixtures, this bond can be broken when they are wet underwater, and in case of seismic activity (earthquakes). In such a case, the intergranular friction may become zero, leading to a state called "liquefaction", when the net allowable bearing capacity also becomes zero, as the shear strength of water is zero. If this happens, excessive settlements and cracks may occur in the tunnel structure [5].
The next step is to determine the maximum net vertical stress increase, $\mathrm{P}^{\prime}{ }_{\text {net }}$ due to construction of the tunnel and its subsequent operation, including the possibility that tunnel may be temporarily full of water, but should not float when the water is emptied. Thus, $\mathrm{P}_{\text {net }}$ is calculated from equation 10 and amounts to $75,2 \mathrm{kPa}$.

$\mathrm{P}_{\text {net }}^{\prime}=\mathrm{P}_{\text {full }}+\mathrm{P}_{\text {seawater }}+\mathrm{P}_{\text {protective layer }}+\mathrm{P}_{\text {traffic }}+\mathrm{P}_{\text {buoyancy }}$

where:

$\mathrm{P}_{\text {net }}^{\prime} \quad$ - the net maximum vertical stress increase, resulting from tunnel construction $(75,2 \mathrm{kPa})$,

$P_{\text {full }} \quad$ - the maximum vertical stress increase $/ m$ at the base level, when the tunnel structure itself is filled with water $(159,2 \mathrm{kPa})$,

$\mathrm{P}_{\text {seawater }}$ - the acting $18,5 \mathrm{~m}$ of positive seawater pressure/ $\mathrm{m}$ above the tunnel $(179,7 \mathrm{kPa})$,

$\mathrm{P}_{\text {protective layer }}$ - the maximum vertical stress increase/m, due to placement of protection stone above the tunnel $(23,5 \mathrm{kPa})$,

$P_{\text {traffic }}$ - contribution to the maximum vertical stress increase/m due to traffic load generated by vehicles passing through the tunnel $(5,4 \mathrm{kPa})$,

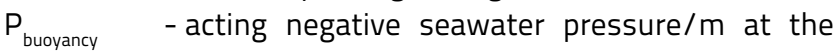
tunnel's base level $(290,7 \mathrm{kPa})$.

In order to calculate total settlements, the net pressure on the seabed soil at the foundation (i.e. base) level has to be calculated. As immersed tube tunnels are constructed in dredged ditches, the pressure relief at the foundation soil, due to trench excavation, has to be considered. First the net pressure increase at the tunnel's base soil is determined from the following equation 11 using the submerged weight of the soil excavated in the dredged ditch $(63,1 \mathrm{kPa})$ :

$P_{\text {excavation }}=\mathrm{H}_{\text {iarka }}+\mathrm{Y}_{\text {soil }}^{\prime}$

By extracting this result $(63,1 \mathrm{kPa})$ from that of the equation $11(75,2 \mathrm{kPa})$, the net soil pressure increase at the tunnel's base level amounts to $12,1 \mathrm{kPa}$. (it should be noted that such a small difference of $12,1 \mathrm{kPa}$ in the net stress between the equations 11 and 12 arises from different unit weights, and volumes in tunnel's cross-section occupied by concrete and water, compared to those of the excavated soil, which covers the whole cross-sectional area. It should also be noted that this value for the Istanbul-Marmaray Project's immersed tube tunnels, now under construction, is $15,0 \mathrm{kPa}$ [1].

This value of $12,1 \mathrm{kPa}$ is called the net soil pressure increase and, for comparison, it is above the allowable soil bearing capacity value of $4,4 \mathrm{kPa}$ for the maximum $25 \mathrm{~mm}$ tolerable total settlement. This means that allowable total and differential settlements will be excessive before soil improvement, and that they can not be tolerated. Hence, soil improvement should be conducted so as to ensure that all settlements are 
tolerable along the entire alignment of the tunnel. Using the finite element method (FEM) and the SAP 2000 software, the vertical displacement (settlement) of a $100 \mathrm{~m}$ long immersed tunnel tube unit can be calculated as follows: The tube unit is divided into 335 solid elements. The coefficient of subgrade reaction (i.e. the spring constant) can be determined using both of the elasticity modulus and the ultimate bearing capacity procedures. A smaller of the two values is taken as the safe k-value, and is adopted in calculations. The FEM model used for tunnel units [2] is shown in Figure 7.

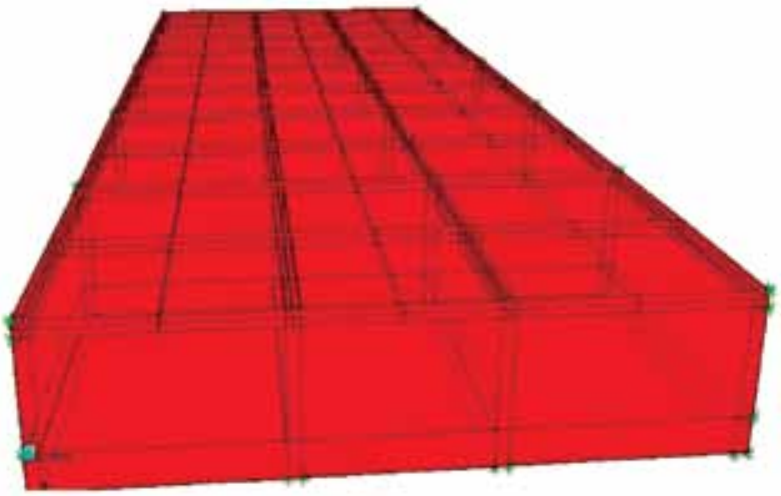

Figure 7. FEM model of a $100 \mathrm{~m}$ long IBITT unit developed using the SAP 2000 software

The vertical settlement depends on load exerted on soil, but also on the subgrade reaction coefficient $\left(k_{s}\right)$, which is in turn related to elasticity modulus ( $E$ ). If the $E$ value of a soil is high, this means that the soil is dense and, hence, a lower settlement value is expected. The elasticity modulus of soil is determined by laboratory testing of undisturbed soil samples extracted from three boreholes situated close to the proposed tunnel alignment (Figure 5) during a previous site investigation conducted in Izmir Bay. These data and records are included in the site investigation reports prepared by the Turkish State Ports and Airports Authority's (DLH) Regional Directorate in Alsancak-Izmir, Turkey [2,3,4]. These previous records indicate that E-values vary between 2 and $20 \mathrm{MPa}$. While awaiting for a detailed S.I., which is to be conducted during the next full feasibility stage, the minimum values of $\mathrm{E}=2 \mathrm{MPa}$ and the Poisson's value of $\mu=0,35$ were adopted to calculate total settlements under the tube units by the FEM, for the stage before the planned ground improvement by compaction grouting technique. By using the subsoil data, the coefficient of (vertical) subgrade reaction $\left(k_{s}\right)$ was established from the following equation 14 [6], It amounts to 233672 N/ $\mathrm{m}^{3}$ or to $233,672 \mathrm{kPa} / \mathrm{m}[2]$.

$k_{s}=\frac{1}{B^{\prime} \cdot E_{s}^{\prime} \cdot I_{s} \cdot I_{f}}[\mathrm{kPa} / \mathrm{m}]$

where:

$B^{\prime}$ - half of the tunnel width,

$\mathrm{E}_{\mathrm{s}} \quad$ - corrected elasticity modulus $\left(1-\mu^{2} / \mathrm{E}_{\mathrm{s}^{\prime}} \mu=0.35 ; \mathrm{E}_{\mathrm{s}}=2 \mathrm{MPa}\right.$;

$\mathrm{I}_{\mathrm{s}}$ and $\mathrm{I}_{\mathrm{f}}$ - chart based influence factors $(0,575$ and 0,85$)$ from $[6]$.
On the other hand, the soil's coefficient of subgrade reaction $\left(\mathrm{k}_{\mathrm{s}}\right.$ ) amounting to $175,000 \mathrm{~N} / \mathrm{m}^{3}$ or $175 \mathrm{kPa} / \mathrm{m}$ [2] was established using an another empirical formula, as shown in the following equation 13 [6]:

$\mathrm{k}_{\mathrm{s}}=40000 \times \mathrm{q}_{\mathrm{s}}[\mathrm{kPa} / \mathrm{m}]$

where 40000 is a constant multiplier and " $q_{a}$ " is the net allowable bearing capacity, taken as being equal to the the smaller of $q_{a(1)}$ and $\mathrm{q}_{\mathrm{a}(2) \text {, }}$ values, and thus amounting to $\mathrm{q}_{\mathrm{a}}=4,4(\mathrm{kPa})$.

As the coefficient of subgrade reaction $\left(k_{s}\right)$ defined in equation 13 is smaller than the one defined in equation 12 , the value $k_{s}=$ $175 \mathrm{kPa} / \mathrm{m}$ was adopted for the IBITT alignment. The SAP 2000 FEM software [2] was used to conduct a vertical displacement analysis using this $k_{s}$ value for the foundation soil with an effective stress increase of $12,1 \mathrm{kPa}$, due to placement of the tunnel onto the seabed soil. According to results obtained by this 2D FEM software, the total settlement of seabed soil at the foundation level amounts to $65,9 \mathrm{~mm}$, which greatly exceeds the maximum tolerable total settlement value of $25 \mathrm{~mm}$ [4]. This shows that soil improvement is necessary. After the soil improvement (by compaction grouting), the excessive total and differential settlements may be reduced, but should be checked in order to see whether they remain within tolerable values of $25 \mathrm{~mm}$ and $12 \mathrm{~mm}$, respectively [4].

\section{Preliminary seismic analysis of the tunnel}

In general terms, buried structures are less affected by earthquakes, compared to similar structures built above the ground level [7]. Until the early 1960s, seismic effects did not have to be taken into consideration in the design of buried structures [8]. In fact, the first immersed tube tunnels, which proved that underground structures may also suffer from earthquakes, were the Alamada Immersed Tube Tunnels in San Francisco, which were constructed between the years 1927 and 1963, without taking into consideration possible earthquake effects. However, during the 1983 Loma-Prietta Earthquake, serious cracks occurred in ventilation shafts of the Alamada Tubes, and the seawater flooded the tubes. It should be noted that, if these tunnels were designed by taking into account the seismic waves (like the BART Tunnel in San Francisco or the South-Port Tunnel in Osaka), no-damage would have occurred and safety would be maintained during similar earthquakes [9].

The seismic behaviour and design of tunnels differs from the behaviour and design of structures built above ground. As immersed tunnels are confined within surrounding soil inside the trench, they are not subjected to vibration amplifications. In case of on-ground structures there is no confinement, and so they are subjected to almost full amplification of shaking motions, depending on their own vibratory characteristics. Tunnels feel earthquake excitations on one-to-one basis, just like the surrounding soils. Thus they should suffer less 
deformation during similar earthquakes [8]. There are two kinds of deformations that affect immersed tube tunnels during earthquakes:

- Axial and lateral deformations: The axial deformation is more destructive than the shrinking deformation. Because the axial (lateral) rigidity of an immersed tube tunnel amounts to about 1/10th of its vertical rigidity [10], the tunnel axial deformations should be calculated and compared with tolerable values at the preliminary design stage.

- Shrinking deformation: If an earthquake wave acts in the direction perpendicular to the tunnel axis, then the shrinking deformation is obtained. If the tunnel structure is conceived in such a way to mitigate adverse effects of deformations that are likely to occur during seismic action, then a safer tunnel structure can be designed and constructed [10]. It was adopted that the dynamic design parameters of the proposed IBITT will be similar to those adopted for the Izmir Metro Part I, as summarized below [11].

- Earthquake Magnitude of Richter Scale 7

- Earthquake Wave Length: 730 m

- - Earthquake Wave Period: 4,62 sec

- Measured Shear Wave Velocity, $V_{s}=100 \mathrm{~m} / \mathrm{sec}$

- Earthquake Wave Velocity or Apparent Seismic Wave Velocity, $C_{a}=130 \mathrm{~m} / \mathrm{sec}$

- Shear Wave Velocity $\left(\mathrm{V}_{\mathrm{s}}\right)^{\prime}$ 's angle to hit the tunnel, $\beta=45^{\circ}$ (with respect to longitudinal axis)

There are no known faults directly intersecting the proposed Izmir Bay Immersed Tube Tunnel (IBITT)'s alignment. However there are some inactive and secondary faults in the area as shown in Figure 8 below [2]. Major active fault is Gülbahçe Fault, which runs in the N-S direction and is nearly at $80 \mathrm{~km}$ distance (west) to IBITT's alignment. This fault generates usually maximum Richter Scale: 4-6 and shallow (usual depth below seabed, $d<5 \mathrm{~km}$ ) earthquakes, whose epicenters generally lie offshore in the South Aegean Sea and are within $20 \mathrm{~km}$ distance (south) of Sığacık village, which is located at about $60 \mathrm{~km}$ southwest of the proposed IBITT's alignment.

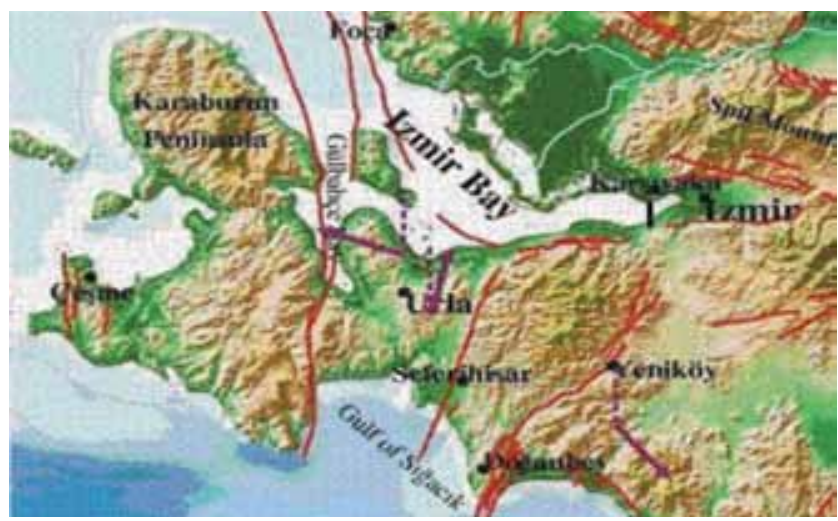

Figure 8. Presence of known faults near to the proposed IBIIT's alignment
Shear wave velocity, $V_{s}$ mesurements below the Izmir Bay's loose to very loose non-cohesive seabed subsoils were done (figure 9) under a different study by others [12]. Such measurements were done at 3 locations, which were were within the maximum $50 \mathrm{~m}$. distance to the proposed IBITT's alignment boundaries. Taking the middepth of the proposed IBITT structure as $15 \mathrm{~m}$ below the seabed, gives us $100 \mathrm{~m} / \mathrm{sec}$. Considering $V_{s}$ hit angle of $\beta=45^{\circ}$ and using the equation 16 , $C_{a}=140 \mathrm{~m} / \mathrm{sec}$ is obtained.

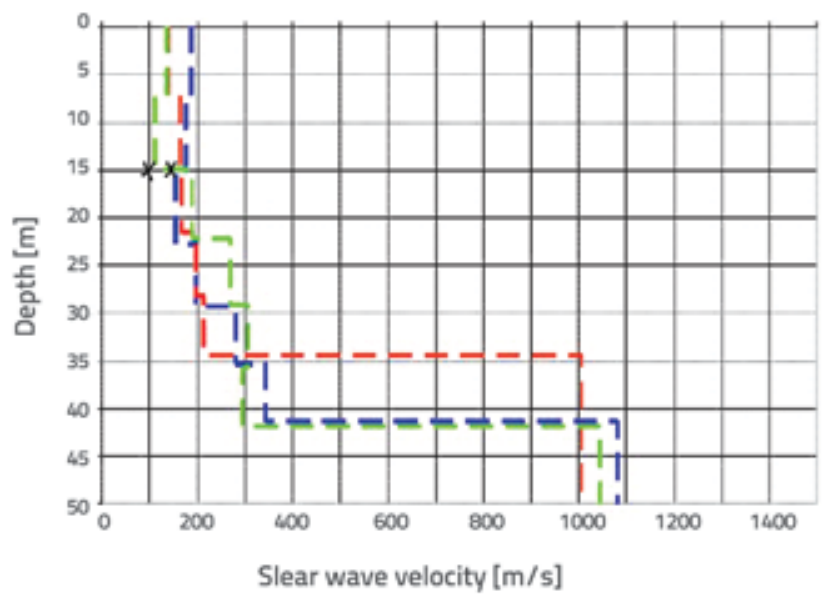

Figure 9. Shear Wave Velocity (Vs) measurements within the Izmir Bay's loose seabed soils near to proposed IBIIT's alignment

This obtained value is very close value to $V_{s}=130 \mathrm{~m} / \mathrm{sec}$ value used in the design-construction of the the Izmir Metro's 1st part (betwen Halkapınar-Üçyol stations), which is now operational for some years [11]. Rather than taking the shear wave velocity $\left(\mathrm{V}_{\mathrm{s}}\right)$ values as they are, the apparent seismic wave velocity $\left(C_{a}\right)$ values should be used, as presented in the following equation 14 [15-18].

$\mathrm{C}_{\mathrm{a}}=\mathrm{V}_{\mathrm{s}} / \sin \beta$

Although some researchers [13-14] recommend the use of $C_{a}>$ $1000 \mathrm{~m} / \mathrm{sec}$ values for California and Japan, while the EC 8 [19] suggests the use of $C_{a}=1000 \mathrm{~m} / \mathrm{sec}$ as a lower bound figure, given the current limited availability of the detailed local field test site investigation data, and recommendations presented in references $[2,11,12]$, it was concluded that the value of $C_{a}=130$ $\mathrm{m} / \mathrm{sec}$ can be adopted at this preliminary design stage, and that it can be modified if subsequent site investigation tests point to an another direction. In this way, the contradiction with the existing local references will be avoided.

In the scope of the seismic analysis of the proposed IBITT, a $1800 \mathrm{~m}$ long section corresponding to about 3 wave-lengths, and consisting of eighteen one hundred m long tube units, was modelled by means of the SAP 2000 FEM software. This modelling was conducted to: 
- calculate maximum stresses that could develop in the tunnel concrete, due to axial deformation of tube units during a $\mathrm{M}=7$ earthquake

- investigate whether any soil improvement was needed, due to dynamic loads acting on the tunnel during a $M=7$ earthquake.

1926 twenty $m$ long solid elements with 3456 nodes were considered in the adopted FEM software model. It is emphasized that, unlike drilled underground tunnels built in hard rock, where the deformations of the tunnel and underground cavity take place separately, the buried structures (like immersed tube tunnels) and tunnels built in loose/soft soils, stay to some extent in interaction with the surrounding soil (and are assumed to deform equally) during an earthquake [10].

As the foundation soil of the proposed IBITT generally consists of very loose to loose granular silt and sand, the interaction (e.g. equal deformation) between the tunnel structure and the surrounding soil should be considered both in the preliminary design and in detailed design. Thus the proposed IBITT's foundation level soil, which has been assigned the coefficient of subgrade reaction value $(174,5 \mathrm{kPa} / \mathrm{m})$, is described in the SAP 2000 FEM software as springs existing on the solid surface. An elastomeric bearing, with the elasticity modulus of $E=3 \mathrm{MPa}$, and Poisson's Ratio of $\mu=0,49$, allowing a lateral differential movement of up to $0,3 \mathrm{~m}$, has been installed so as to enable flexible movement between the two tubes situated next to one another. Just like in design criteria adopted for the Marmaray Project [1], a seismic-joint, allowing a lateral differential movement of up to 0,5 m was placed between the two tube units at each end of the flat (slope $=0 \%$ ) middle section

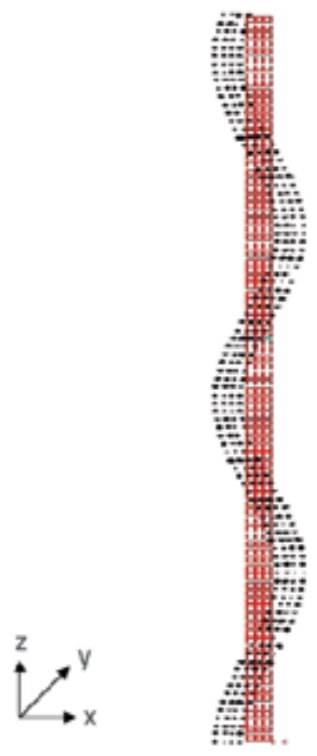

Figure 10. Proposed IBITT tunnel deformation during a $M=7$ earthquake, due to connected prefab units
The flat middle section is $3660 \mathrm{~m}$ long and it contains thirtysix 100 m long tube units, a length which is equal to about 6 times the expected $M=7$ earthquake wave's length in Izmir (i.e. $600 \mathrm{~m}$.). Thus, instead of using a 6 times earthquake wavelength distance, a half length of 3 times earthquake wavelength distance of $1800 \mathrm{~m}$ was adopted in the modelling. This corresponds to the length of 18 tube units. In addition, the model allows for free movement of each entrance (portal) unit of the proposed IBITT during an $\mathrm{M}=7$ earthquake without compromising safety. It can therefore be concluded that the adopted model is appropriate, and that deformation calculations performed are correct. As stated earlier, in case of buried structures or immersed tube tunnels founded on loose soil, the tunnel and the surrounding soil interact and yield the same amount of deformation during any earthquake in an active fault region [10]. This phenomenon is also considered valid for the proposed IBITT structure and for its foundation soil, as shown in Figure 10 [2].

Since no single national tunnel design specification is currently used in Turkey, design loads for the proposed IBITT have been taken from similar specifications prepared in earthquakeprone regions of some Far-East countries [4], as shown in the following equation (15):

$1 D L+1 L L+1 E U$

where:

DL - dead load, due to tunnel's own (submerged) weight, including the protective layer's submerged weight above the tunnel, and the water-column weight above the tunnel,

LL - live load weight inside the tunnel (vehicles, traffic etc,)

EU - earthquake load, resulting from lateral displacement of tunnel during an earthquake.

Assuming that the tunnel suffers maximum damage when a $M=7$ earthquake wave hits at an angle of $45^{\circ}$ to the tunnel's longitudinal axis (the case when the maximum earthquakewave height amounts to $1 \mathrm{~m})$ [10], the tunnel's lateral displacement $\left(y_{i}\right)$ at an angle of $90^{\circ}$ to the longitudinal axis is calculated using the following equation (16):

$y_{i}=D \cdot(\cos \alpha) \cdot\left(2 \pi \cdot \frac{x_{i}}{L / \cos \alpha}\right)[m]$

where:

D - wave height (m)

a - angle between the tunnel's longitudinal axis and the earthquake wave's direction (in degrees)

$\mathrm{L}$ - earthquake wave length (m)

$x_{i}$ - tunnel's longitudinal displacement (m) along the longitudinal axis

$y_{i}$ - tunnel's lateral displacement $(\mathrm{m})$ at an angle of $90^{\circ}$ to the longitudinal axis 
As a result, the maximum compressive stress in lateral direction amounts to $45,5 \times 10^{6} \mathrm{~N} / \mathrm{m}^{2}$, while in longitudinal direction it amounts to $21 \times 10^{6} \mathrm{~N} / \mathrm{m}^{2}$, as shown in Figures 11 and 12 [2].

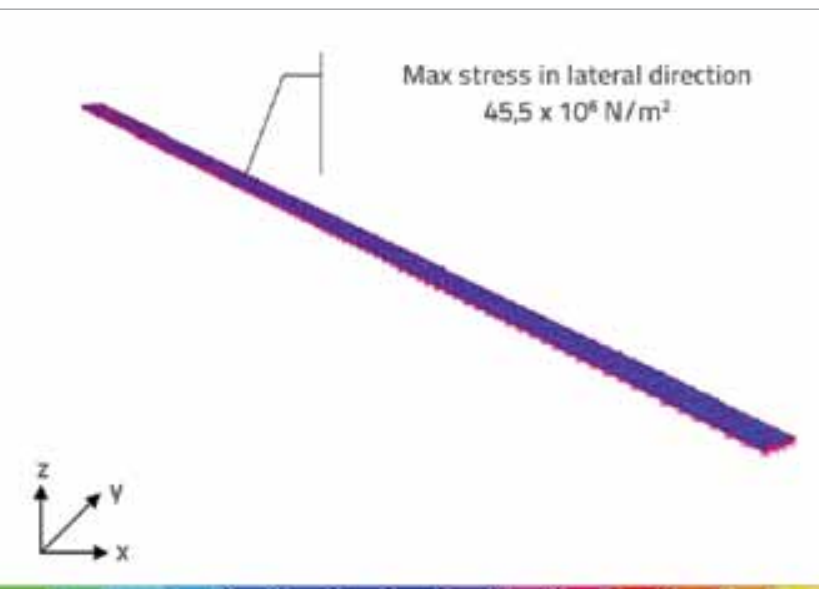

Figure 11. Proposed IBITT maximum concrete stress in lateral direction during a $\mathrm{M}=7$ earthquake before soil improvement

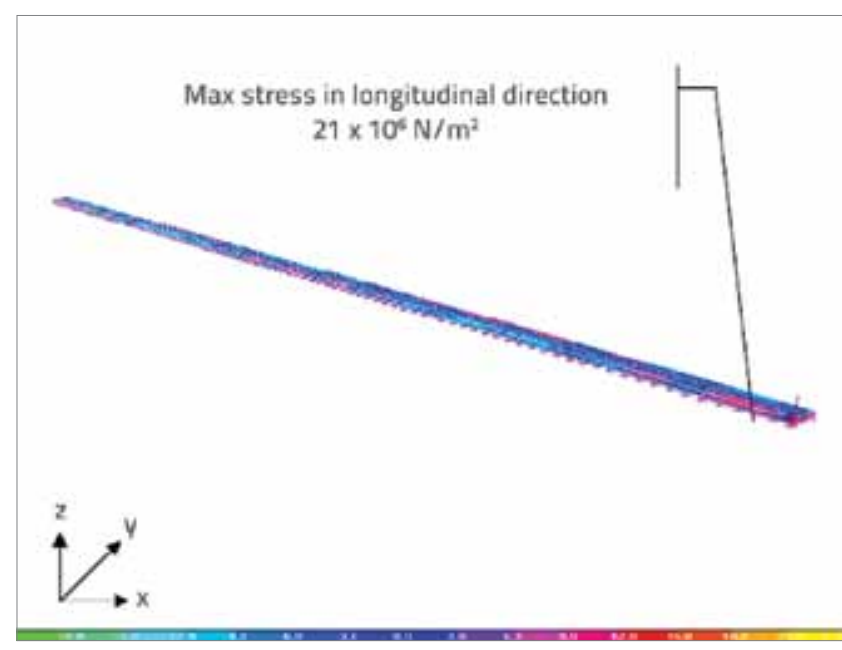

Figure 12. Proposed IBITT maximum concrete stress in longitudinal direction during a $\mathrm{M}=7$ earthquake before soil improvement

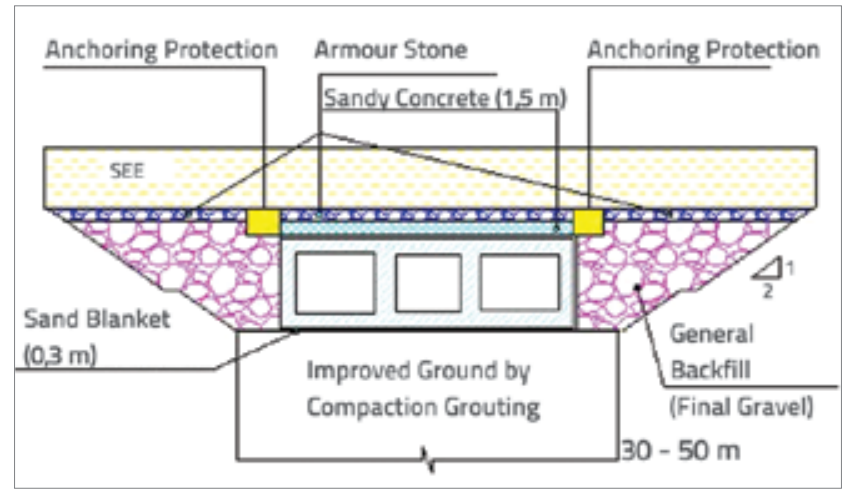

Figure 13. Final cross-section of the proposed IBITT after backfilling and soil improvement
Since the maximum stresses obtained exceed the design compressive strength of the concrete to be used on the project (20 MPa), the seabed soil will have to be improved in the length corresponding to the entire length of the alignment, and in the width of $42 \mathrm{~m}$ (corresponding to the width of the tunnel tube units plus one metre on each side). Calculations were repeated until it was demonstrated that the maximum allowable compressive stress in the tunnel's concrete (i.e. concrete strength) will not be exceeded. The final section of the proposed IBITT in its dredged ditch, after soil improvement and after trench backfilling, is shown in Figure 13 [2].

\section{Soil improvement}

Using the existing limited subsoil data to perform settlement calculations, it has been established in the course of this preliminary analysis and design that sea-bed soil below the tunnel will have to be improved, due to varying thicknesses of loose to very loose granular deposits above the bedrock (rockhead) level, which dips towards north up to about $280 \mathrm{~m}$. In this case, the most suitable soil improvement method is the so called 'compaction grouting'. This technique has also been applied at the Marmaray Immersed Tube Tunnel Project in Istanbul, Turkey [1], as well as on some other worldwide projects having similar foundation soil.

The compaction grouting is a soil improvement method by which the goal of compacting very loose to loose silts-sands mixtures can be achieved, provided that their fines content is low to medium ( $<30 \%$ ), as in this case the methods has proven to be the most efficient. In fact, the efficiency of the method increases with an increase in overburden stress or with the soil depth below the sea-bed. Sea-bed surface deposits less than $1 \mathrm{~m}$ in thickness, characterized by high (>30\%) fines contents, could be removed or mixed in-situ with clean sand to increase the method's efficiency. According to this method, a very stiff (slump $<25 \mathrm{~mm}$ ) fine-cemented mortar grout is injected at moderate pressure (ranging from 10 to 70 bars) into the soil through a drill hole $100-150$ in diameter. The grouting process starts at the bottom of the drilled hole (when the maximum improvement depth is reached) and it advances continuously, while the grouting depth is reduced or the casing is withdrawn in stages.

Thus at any grouting stage, when the grout bulb expands, the surrounding soil experiences some shear deformations away from the bulb. Such shear deformations cause rearrangement of granular soil particles into a denser packing. The resulting displacement of soil particles under pressure causes volumetric compaction while in-situ cementation is caused by the injected fine-cement grout, which increases the in-situ shear strength of soil. While the grid size can range between 1 to $3 \mathrm{~m}$, the method requires verification testing for quality control, so as to check whether the required density is achieved or not (like static cone penetrometer tests) for the before and after stages. Also, the use of quick hardening and durable cements in sea water should be preferred [4]. 
By applying this method, the subsoil can become stiffer, its properties are improved, the bearing capacity is increased, the liquefaction risk is reduced, the short term (during construction) and long term (30 years after construction) total and differential settlement values become tolerable, and the response of soil to the expected lateral and longitudinal dynamic load during a potential $\mathrm{M}=7$ earthquake is improved. It has become clear in this preliminary design stage that the minimum soil density in varying soil improvement depths should be increased so that the minimum SPT-N value to be achieved after ground improvement amounts to 35 (corresponding to dense soil state). This value will enable the maximum stress in the tunnel concrete (because of axial deformation of the tunnel, due to a $\mathbf{4 5}$ degree lateral earthquake force occurring in the Izmir Bay) to cause tolerable (i.e. smaller) concrete stress than the tunnel concrete's own design compressive strength of $20 \mathrm{MPa}$.

The proposed soil improvement will be made for a minimum depth of $30 \mathrm{~m}$ in south section with its portal area, where the minimum SPT-N=35 will be achieved and verified with in-situ tests for the entire tunnel alignment length $(7,6 \mathrm{~km})$ with the width of $42 \mathrm{~m}(2 \mathrm{~m}$ wider than the tunnel width of $40 \mathrm{~m}$ ). But below this improved stiff layer, there will be another triangularly-shaped less stiff zone (with a minimum $\mathrm{SPT}-\mathrm{N}=15$ ), whose depth will be zero in the south, but no less than $20 \mathrm{~m}$ in the north, where thicker loose deposits exist above the bedrock, Figure 14.

When doing the soil improvement works, it's recommended for the first stage to do the soil improvement of the top 30 $\mathrm{m}$ for the whole alignment length. A sand blanket layer thickness of at least 0,3 $\mathrm{m}$ shoud be imbedded in order to provide uniform load distribution on the foundation level, and placed above the ground improvement, but beneath the tunnel base. The longitudinal section of the proposed IBITT after soil improvement by compaction grouting is shown in Figure 14 [2].

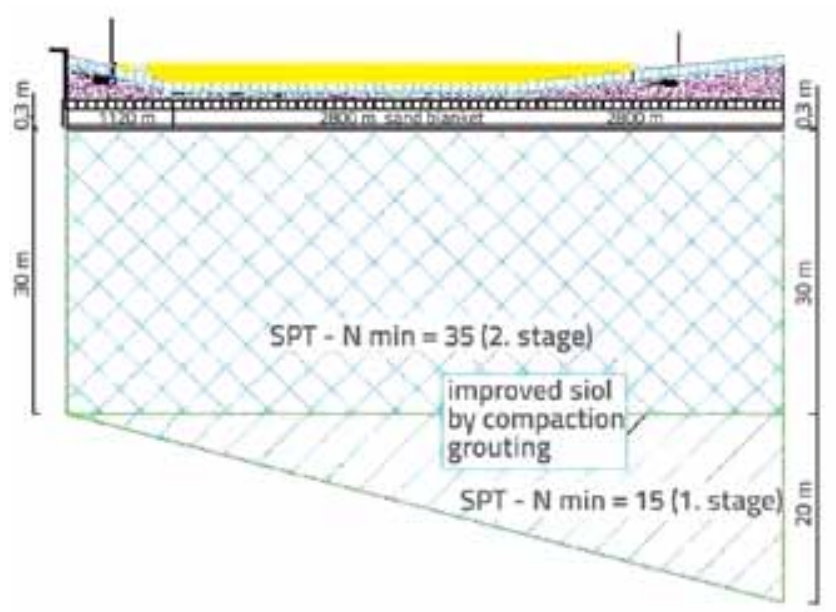

Figure 14. Longitudinal section of the subsoil at the proposed IBITT, after soil improvement
Stress states of concrete tunnel tube in lateral and longitudinal directions after the soil improvement are shown in Figures 15 and 16 [12]. All FEM analyses of tunnel tube behaviour performed as a part of the preliminary design in the pre-soil improvement stage and post-improvement stage are shown in Table 1.

Table 1. Results of preliminary design analyses before and after soil improvement for the IBITT project

\begin{tabular}{|c|c|c|}
\hline Criteria & $\begin{array}{l}\text { Before soil } \\
\text { Improvement } \\
{\left[\mathrm{N}_{\mathrm{AV}}=4\right]}\end{array}$ & $\begin{array}{c}\text { After soil } \\
\text { Improvement } \\
{\left[\mathrm{N}_{\mathrm{Av}}=35\right]}\end{array}$ \\
\hline $\begin{array}{l}\text { Bearing capacity } \\
{\left[\mathrm{t} / \mathrm{m}^{2}\right]}\end{array}$ & 0,44 & 14,27 \\
\hline Soil liquefaction risk & $\begin{array}{c}\text { FS }<1.25 \\
\text { (high liquefaction } \\
\text { risk) }\end{array}$ & $\begin{array}{c}\text { FS }>1,25 \\
\text { (low liquefaction } \\
\text { risk) }\end{array}$ \\
\hline $\begin{array}{l}\text { Maximum settlement } \\
{[\mathrm{cm}]}\end{array}$ & 6,59 & $\begin{array}{c}2,2<2,5[4] \\
\text { (satisfy) }\end{array}$ \\
\hline $\begin{array}{l}\text { Maximum stress in } \\
\text { tunnel concrete } \\
\text { due to its axial } \\
\text { deformation } \\
\text { [MPa] }\end{array}$ & 45 & $\begin{array}{c}19,6-19,9<20 \\
\text { (satisfy [21]) }\end{array}$ \\
\hline
\end{tabular}

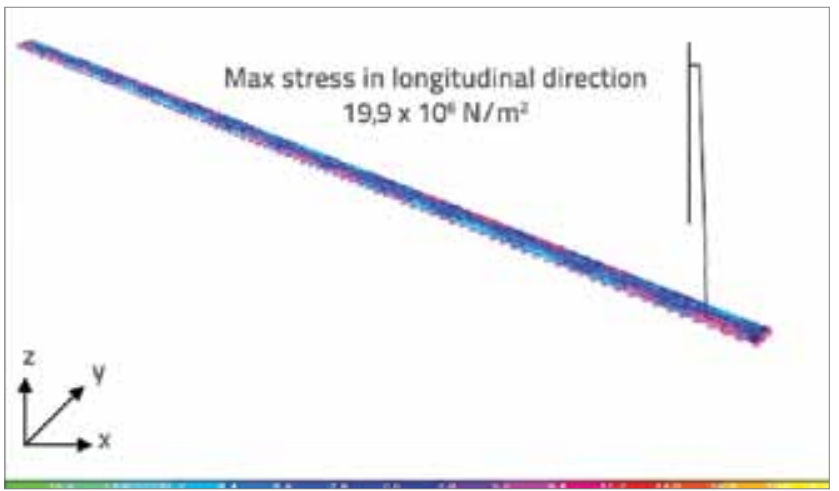

Figure 15. Proposed IBITT maximum concrete stress in the longitudinal direction during a $\mathrm{M}=7$ earthquake after soil improvement

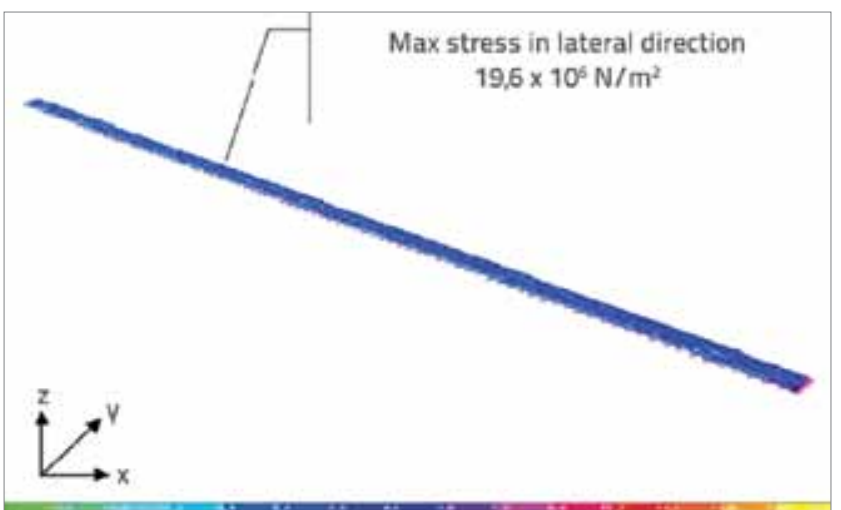

Figure 16. Proposed IBITT maximum concrete stress in the lateral direction during a $\mathrm{M}=7$ earthquake after soil improvement 
The design of structural sections and reinforcements for the IBITT project (to take into account static or dynamic earthquake forces, stresses and bending moments) is a process that is normally conducted at the detailed design (DD) stage.

As a part of the preliminary design, vertical springs (i.e. vertical coefficient of subgrade reaction) were used in calculations to estimate allowable bearing capacity of sub-soil below the IBITT's base, as well as the IBITT's expected maximum (vertical) total and differential settlements, before and after the specified type of soil improvement If any modifications are made to soil improvement, either in specifications or in scope, then calculations should be reviewed/repeated.

Another key parameter to be taken into account at the DD stage of an immersed tunnel is the response of flexible immersion joints (rubber gaskets and secondary waterproofing membranes), as the rubber-gasket installation will require a minimum longitudinal compression threshold value to maintain their axial rigidity and water-tightness of the tunnel. If gaskets are subjected to excessive longitudinal compression, they may fail due to tension perpendicular to the direction of the load (termed as Poisson's Ratio effect). Thus as a precaution, secondary seal joints are usually installed (as their operation does not require any compression threshold). Furthermore, tendons that join two successive tubes together are installed as a second line of defence, in order to assume a limited amount of tension forces, arising from possible lateral tensile strains occurring during an earthquake. Therefore, when designing rubber gaskets, the levels of working compressive stresses assumed per $1 \mathrm{~m}$ length of gasket perimeters must be checked to see whether they are at their allowable load levels (usually within 4-8 $\mathrm{MN} / \mathrm{m}$ ) with respect to the material capacity (elastic range) of gaskets. Finally, as full decompression of rubber gaskets and mobilization of tendon action is avoided in a proper design of immersed tunnels, a good engineering practice is to regularly check the status of the gaskets and tendons for proper functionality, including mandatory checking after each earthquake, and to take necessary precautions, if needed (including their replacement or installation of new gaskets made of innovative materials).

\section{Conclusions}

Preliminary results obtained in the course of this study show that construction of the proposed IBITT project at the Izmir Bay is feasible provided that the specific "compaction grouting" soil improvement technique is conducted properly. The most important factor for post-improvement of the insitu density by applying an appropriate soil improvement method is to obtain a minimum level of stiffness so as to achieve the best possible soil-structure interaction in case of a severe $(M=7)$ earthquake. For this, a minimum postimprovement SPT-N value, compatible with the immersed tube's concrete material, must be obtained. In other words, "the minimum post-improvement soil-structure interaction stiffness level" requirement (introduced for the first time in technical literature for checking design and construction of immersed tunnels) must be met, in addition to other usual geotechnical criteria (i.e. maximum allowable bearing capacity, maximum allowable total-differential settlements, and minimum liquefaction risk).

Furthermore, using the existing sub-soil data relevant for the IBITT project, it was demonstrated for the first time that, if "the minimum post-improvement stiffness level" criteria for an immersed tunnel design are satisfied, then all other usual geotechnical criteria are also satisfied, which means that the former criteria should be more stringent.

\section{Acknowledgement}

This manuscript is based on study conducted at the Graduate Studies Institute (GSI) and the Civil Engineering Department of the Izmir Institute of Technology in Izmir, Turkey. The authors acknowledge the structural engineering support given by the colleagues Asst. Prof. Gürsoy Turan, and Assoc. Prof. Engin Aktaş. The authors would also like to extend their thanks to the State Ports and Airports Authority - DLH, and especially to its Regional Office in Izmir-Turkey, for providing geotechnical site investigation data for the zone closest to the proposed IBITT alignment.

\section{REFERENCES}

[1] Marmaray Project http:// marmaray.com, İstanbul, Turkey.

[2] Kartaltepe N.: "Preliminary Design and Analysis for an Immersed Tube Tunnel across the Izmir Bay", M.Sc. Thesis, Civil Engineering Dept., www.iyte.edu.tr, Izmir,Turkey, 2008.

[3]. Teng, W.C.: "Foundation Design", Prentice-Hall Inc., Englewood Cliffs, N.J., USA, 1962.

[4] Egeli, I.: "Western Harbour Crossing Immersed Tube Tunnel: Design and Construction Aspects" Internal Report, MGSL, Hong Kong, China, 1996.

[5] Cinicioğlu, S.F.: "Zeminlerde Statik ve Dinamik Yükler Altında Taşıma Gücü Anlayıșı ve Hesabı Yapı Tasarımı Kurs Notları." (in Turkish), IMO, Istanbul, 2005.

[6] Bowles, J.E.: "Foundation Analysis and Design", Mc Graw Hill, International Ed., Singapore, 1988.

[7] Kouretzis, G.P.: Bouckovalas, G.D., Gantes, C.J.:"3-D Shell Analysis of Cyclindrical Underground Structures under Seismic Shear (S)Wave Action", Soil Dynamics and Earthquake Engineering, 26, pp.909-921, 2006. 
[8] Taylor, P.R., Hisham H.I., Yang, D.: "Seismic Retrofit of George Massey Tunnel", Earthquake Engineering and Structural Dynamics, 34(4-5), pp.519-542, 2005.

[9] Anastasopoulos I, Gerolymos N., Drosos V., Georgarakos T., Kourkoulis R. and Gazetas G.: "Behaviour of deep immersed tunnel under combined normal fault rupture deformation and subsequent seismic shaking". Bulletin of Earthquake Engineering, 6(2), pp.213, 2007.

[10] Wang, J. W.: "Seismic Design of Tunnels: A Simple State-of-theArt Design Approach", Internal Report, Parsons Brinckerhoff Inc., N.Y., USA, 1993.

[11] Tezcan, S.: "Izmir Metrosu 1.ci Kısım (Halkapınar-Üçyol Hattı) Tasarımı ve İnşaatı- Tasarım Değerlendirme Özeti" (in Turkish) DEU-Müh.Fak.Sunumu, www.deu.edu.tr, Buca-Izmir, Turkey, 2007.

[12] Atakan, K., Bjerrum, L.W., Gungor, T., Ims, M., Rodriguez, M., Sari, C., Walderhaug, H.: "Izmir'de Sismik Tehlikeyi Belirlemek için Deprem Senaryolarına Dayalı Yer Hareketi Simülasyonları ve Paleomanyetik Çalışmalar",Izmir-ARA Semp.,www. izmirafetriski.org,Tepekule-izmir, Turkey, 2009.

[13] O'Rourke, M.J., Bloom, M.C., Dobry R.: "Apparent propagation velocity of body waves", Earthquake Engineering and Structural Dynamics, 10, pp.283-294, 1982.

[14] Okamoto, S.,"Introduction to Earthquake Engineering", 2.nd ed., Tokyo Univ. Press, Tokyo, 1984.
[15] Kiyomiya, O.: "Earthquake resistant design features of immersed tunnels in Japan", Tunneling and Underground Space Technology, 10(4), pp.463-475, 1995.

[16] Abrahamson, N.A., Schneider, J.F., Stepp, J.C.: "Empirical spatial coherency functions for soil-structure interaction analyses", Earthquake Spectra, 7(1), pp.1-27, 1991.

[17] Power, M.S., Rosidi, D., Kaneshiro, J.: "Vol. 3 Strawman: Screening, evaluation and retrofit design of tunnels", Internal Report, National Center for Earthquake Engineering Research, NY, USA, 1996.

[18] Hashash, Y. M. A., Hook, J. J., Schmidt, B., Yao, J.I.: "Seismic design and analysis of underground structures", Tunneling and Underground Space Technology, 16, pp.247-293, 2001.

[19] Eurocode 8, (EC8): 'Design Provisions for Earthquake Resistance of Structures', European Commission for Standardization, Brussels, Belgium, 2002.

[20] Tezcan, S.S., Ozdemir, Z.: "Liquefaction Risk Analysis and Mapping Techniques", Bogazici University-YOEA Foundation Publication no.CV-318 (ISBN:975-93005-1-6), Bebek-Istanbul, 2004.

[21] TS-500-Betonarme Yapıların Tasarım ve Yapım Kuralları (in Turkish),Turkish Standards Institute (TSE), Ankara, Turkey, 2000. 